ZOOLOGIA 27 (5): 789-794, October, 2010

doi: $10.1590 /$ S1984-46702010000500015

\title{
Canaania obesa (Platyhelminthes: Dicrocoeliidae): redescription and new hosts records
}

\author{
Arnaldo Maldonado Junior ${ }^{1}$; Jairo Pinheiro ${ }^{2}$; Raquel de O. Simões ${ }^{1} \&$ Reinalda M. Lanfredi ${ }^{3,4}$ \\ ${ }^{1}$ Laboratório de Biologia e Parasitologia de Mamíferos Silvestres Reservatórios, Instituto Oswaldo Cruz. Manguinhos, \\ 21040-360 Rio de Janeiro, RJ, Brazil. E-mail: maldonad@ioc.fiocruz.br \\ ${ }_{2}^{2}$ Departamento de Ciências Fisiológicas, Instituto de Biologia, Universidade Federal Rural do Rio de Janeiro. Rodovia Rio-São \\ Paulo, km 47, 23890-000 Seropédica, RJ, Brazil. \\ ${ }^{3}$ Laboratório de Biologia de Helmintos Otto Wucherer, Centro de Ciências da Saúde, Universidade Federal do Rio de Janeiro. \\ Avenida Carlos Chagas Filho, Bloco G, 21941-902 Rio de Janeiro, RJ, Brazil. \\ ${ }^{4}$ In memoriam.
}

\begin{abstract}
The digenetic trematode Canaania obesa Travassos, 1944 (Dicrocoeliidae) was described as a parasite of the bile ducts of the rodent Akodon cursor Winge, 1887 (Cricetidae) collected in Santa Teresa, state of Espírito Santo, Brazil. In the present study, we report the occurrence of C. obesa infecting three additional sigmodontinae rodent species: Akodon montensis Thomas, 1913; Oligoryzomys nigripes Olfers, 1818 and Nectomys squamipes Brants, 1827, from three municipalities situated at Serra dos Órgãos, Rio de Janeiro, Brazil. Scanning electron microscopy showed that this helminth has a leaflike shape with conical extremities and the ventral mid body protrudes at the acetabulum level. The microtopography of the tegument shows a heterogeneous surface with smooth or wrinkled areas and several randomly distributed papillae. The cirrus is located just posterior to the oral sucker and is covered by smooth tegument without spines or papillae. The excretory pore is subterminal. The eggs are elliptic and operculate at one of the extremities. The present study adds new taxonomic characters to $C$. obesa. The municipalities of Nova Friburgo, Teresópolis and Sumidouro are new geographical areas of distribution, and $A$. montensis, $O$. nigripes and $N$. squamipes are new host records for $C$. obesa.
\end{abstract}

KEY WORDS. Bile ducts; digenetic; rodents; sigmodontine; trematode.

The Atlantic Rainforest ecosystem, one of the world's biodiversity (Myers et al. 2000) hotspots, has been reduced to seven percent of its original size by anthropogenic activities. Currently, efforts are being made to preserve what is left (Fundação Sos Mata Atlântica \& Inpe 2002). Rodents such as Nectomys squamipes Brants, 1827 (Cricetidae), Oligoryzomys nigripes Olfers, 1818 (Cricetidae), and Akodon spp. Meyen, 1833 (Cricetidae) are largely abundant in this ecosystem, even in disturbed areas (Gentile \& Fernandez 1999).

Canaania obesa Travassos, 1944 (Dicrocoeliidae) was originally described from the bile duct of the wild rodent Akodon cursor Winge, 1887 (Cricetidae) collected in the State of Espirito Santo, Brazil (Travassos 1944). No additional data on this helminth has been published since. Long-term studies on trematode parasites of small wild mammals and their transmission patterns are usually restricted to Schistosoma mansoni Sambon, 1907 and Echinostoma paraensei Lie and Basch, 1967 (MALDONADO JR et al. 2006).

In the present study, $C$. obesa is re-described from the following naturally infected hosts: N. squamipes, A. cursor, A. montensis and $O$. nigripes. We have used light and scanning elec- tron microscopy (SEM) to contribute new morphological features to the species characterization. We have also added new locations to the known geographic distribution of C. obesa, and recorded new vertebrate hosts for it.

\section{MATERIAL AND METHODS}

Rodents were captured in three municipalities of the state of Rio de Janeiro, Brazil: 1) Nova Friburgo ( $22^{\circ} 16^{\prime} 55^{\prime \prime} \mathrm{S}, 42^{\circ} 31^{\prime}$ 52 "W) comprising eleven localities (Baixada Nova Friburgo, Campo do Coelho, Cardinas, Conquista, Córrego Grande, Floresta, Rio Grande, Salinas, Santa Cruz, São Lourenço and Três Cachoeiras); 2) Teresópolis (22 $\left.26^{\prime} 12^{\prime \prime} \mathrm{S}, 42^{\circ} 58^{\prime} 42^{\prime \prime} \mathrm{W}\right)$ with six localities (Bonsucesso, Fazenda Alpina, Mottas, Santa Rosa, Venda Nova and Vieira); and 3) Sumidouro (22 $02^{\prime \prime} 46^{\prime \prime}$, $42^{\circ} 41^{\prime} 21^{\prime \prime} \mathrm{W}$ ) with three localities (Campinas, Dona Mariana and São Bento). All localities are situated in the Serra dos Órgãos, which contains small plantations, pasture lands, and a few small Atlantic Forest fragments (Fig. 1). Rodents were captured between 2000 and 2002 by the Bubonic Plague Survey of the Fundação Nacional de Saúde (FUNASA), which monitored the 


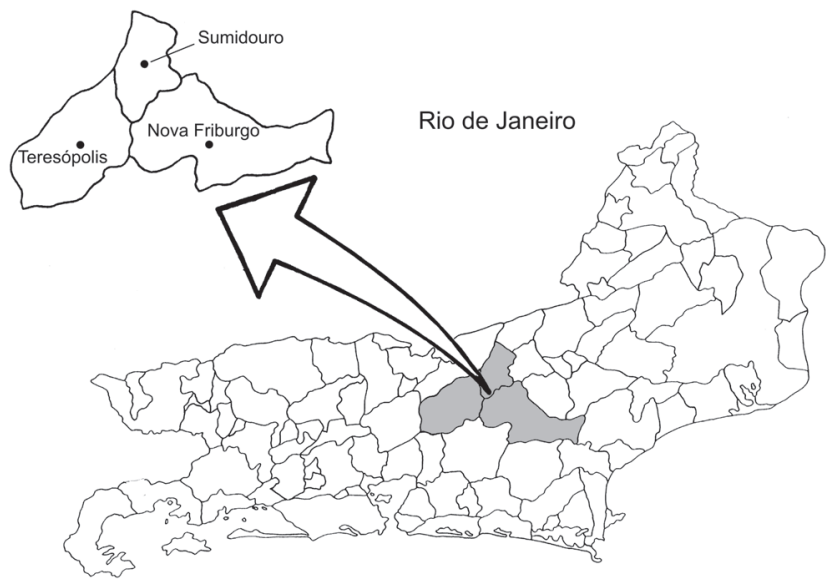

Figure 1. Map of the state of Rio de Janeiro with sampling sites in Nova Friburgo, Teresopolis and Sumidouro.

presence of wild rodents as a reservoir of the Yersinia pestis (Proteobacteria: Enterobacteriales). Standard wire-mesh live traps baited with corncobs were used, and captured subjects were kept in captivity for a week before being euthanized and examined for helminths.

Identifications of Akodon species were carried out by karyotype analysis performed at the National Cancer Institute (INCA), following SEABRIght (1971). The following species were identified: A. cursor, A. montensis and A. serrensis. In the present study Akodon spp. represents rodents with an inconclusive karyotype. Other rodents species studied were identified using morphological characters.
The rodents were serologically investigated for $Y$. pestis and after negative results they were donated for helminthological analyses. Specimens were euthanized by $\mathrm{CO}_{2}$ inhalation and necropsied for worm recovery. Their digestive system was immediately opened in a Petri dish filled with a physiological saline solution $(\mathrm{NaCl} 0.9 \%)$ at room temperature. The collected worms were washed in the same solution, counted and fixed in ethanol-formalin-acetic acid-water solution (AFA) at room temperature. The parasitological terms used follow Bush et al. (1997).

For light microscopy, pre-fixed specimens recovered from each rodent species were rinsed in $70 \%$ ethanol, stained in Langeron's chloride carmine, dehydrated in a graded ethanol series, cleared in methyl salicylate and mounted permanently on slides in Canada balsam. Drawings were made using a Zeiss Standard 20 light microscope with the aid of a drawing attachment. Measurements are presented in millimeters. Paratypes (CHIOC 12053 to 12055) of the related species Conspicuum pulchrum Travassos, 1919 (Dicrocoeliidae) were examined from the helminthological collection of the Instituto Oswaldo Cruz (CHIOC). For SEM, fixed specimens were prepared following the methods in Mafra \& LANFredi (1998) and analyzed and micrographed using a JEOL JSM-5310 scanning electron microscope.

A total of 803 rodents were studied from 2000 to 2002. Of these, 317 individuals were identified as Akodon spp., 423 were O. nigripes and 63 corresponded to $N$. squamipes. The majority of infected rodents were from localities in Teresópolis and Nova Friburgo (Tab. I). The prevalence of C. obesa was $23.3 \%$ for Akodon spp., $0.47 \%$ for O. nigripes and $1.58 \%$ for $N$. squamipes. Rodents in all localities in Nova Friburgo and Teresopólis were infected with $C$. obesa. The highest prevalences of the parasite were observed in A. cursor and A. montensis com-

Table II. Morphometric comparison of C. obesa obtained from A cursor, A. montensis and N. squamipes from Nova Friburgo, Rio de Janeiro and C. obesa from A. cursor from in Santa Teresa, Espírito Santo according Travassos (1944).

\begin{tabular}{|c|c|c|c|c|}
\hline \multirow{2}{*}{ Morphological characters } & \multirow{2}{*}{$\begin{array}{c}\text { Santa Teresa, ES } \\
\text { (Travassos 1944) }\end{array}$} & \multicolumn{3}{|c|}{ Nova Friburgo, RJ (Present study) } \\
\hline & & A. cursor & A. montensis & N. squamipes \\
\hline Body length & $2.4-3.9$ & $2.3-3.2$ & 2.2 & $3.3-4.7$ \\
\hline Body width at acetabular level & $1.1-2.0$ & $1.2-1.6$ & 1.3 & $2.0-2.3$ \\
\hline Oral sucker & $0.22-0.27 \times 0.36-0.39$ & $0.24-0.25 \times 0.38-0.42$ & $0.22 \times 0.28$ & $0.36-0.38 \times 0.50-0.54$ \\
\hline Acetabulum & $0.65-0.68 \times 0.93-0.99$ & $0.67-0.84 \times 0.96-1.02$ & $0.73 \times 0.84$ & $0.86-0.90 \times 1.13$ \\
\hline Oral sucker/acetabulum ratio & $1: 2.17-3.07$ & $1: 2.40-3.12$ & $1: 3.0-3.3$ & $1: 2.26-2.38$ \\
\hline Pharinge & $0.07-0.15$ & $0.12-0.16$ & 0.17 & 0.18 \\
\hline Ceca distance from posterior end & $0.30-0.42$ & $0.20-0.42$ & $0.24-0.26$ & $0.9-1.34$ \\
\hline Testes & $0.30-0.50 \times 0.16-0.38$ & $0.20-0.40 \times 0.30-0.56$ & $0.24-0.28 \times 0.31-0.33$ & $0.18-0.25 \times 0.22-0.38$ \\
\hline Ovary & $0.18-0.36$ & $0.20-0.27 \times 0.27-0.34$ & $0.26 \times 0.33$ & $0.18-0.22 \times 0.25-0.29$ \\
\hline Vitellaria extension (length) & $1.6-1.8$ & $0.6-1.3$ & $0.7-0.8$ & $0.8-1.1$ \\
\hline Vitellaria from posterior end & $0.9-2.7$ & $1.4-16$ & $1.22-1.37$ & $1.54-2.04$ \\
\hline Eggs & $0.022-0.034 \times 0.042$ & $0.13-0.018 \times 0.022-0.035$ & $0.02 \times 0.03$ & $0.01 \times 0.02-0.03$ \\
\hline
\end{tabular}

ZOOLOGIA 27 (5): 789-794, October, 2010 
bined, or in Akodon spp. as a whole, in both localities (Nova Friburgo and Teresópolis), while $O$. nigripes and $N$. squamipes were only marginally infected, showing low prevalence rates. A total of 252 specimens of C. obesa were recovered from Akodon spp., with a frequency distribution of 1 to 41 worms. Twenty nine specimens of Akodon spp. from Nova Friburgo were randomly selected and karyotyped; of these, 13 specimens were identified as $A$. cursor, 11 as $A$. montensis and five as $A$. serrensis. The prevalence of $C$. obesa in the above sample was $15.4 \%$, $18.2 \%$ and $0 \%$, respectively.

\section{TAXONOMY}

\section{Canaania obesa Travasos, 1944}

Figs 2-8

Redescription (comparative measurements in table II): by light microscopy (Fig. 2) C. obesa presents a round body with conical extremities and maximum width at the level of the acetabulum. The oral sucker is subterminal and the acetabulum is situated in the middle of the body, being two to three times larger than the oral sucker (Tab. II). The caeca are long and do not reach the end of the body. The testes are situated in the middle of the body, posterior to the acetabulum. The cirrus pouch is ovoid and postero-dorsal to the acetabulum and occasionally protruded. The ovary is single, laterally located, and opposed to the testes. The uterus filled with eggs is responsible for the round body shape, frequently seen in Dicrocoeliidae. Its loops occupy the posterior and anterior regions of the body, and are extensively distributed at the anterior half, giving the acetabulum a C- shaped appearance. Vitellaria are distributed from the preacetabular region up to $2 / 3$ of the body length, not overlapping the end of the caeca; the vitelline duct is a tubular structure next to the ovary. Specimens collected from $N$. squamipes and $O$ nigripes presented the same features as the ones obtained from A. cursor, except for the size. Worms recovered from $N$. squamipes (Tab. II) were in average larger.

Examination using SEM (Figs 3-8) revealed that the worm body is "leaf like" in shape with conical extremities, having the central ventral region protrudent, widest at the level of the acetabulum. The shape described above, however, is influenced by the degree of contraction of the body at the moment of fixation. The tegument is smooth, without spines, and may present parallel corrugations with spherical protuberances, depending of the degree of contraction of the body. The papillar distribution on the body surface follows a gradient, with a higher concentration and organization at the anterior region which decrease posteriorly. The mouth opening is subterminal with the larger axis transversal to the body; the oral sucker presents concentric corrugations with several tubercles around it, differing from the body tegument. When the sucker is contracted, the internal musculature of the sucker is more evident. The genital atrium is located just posterior to the oral sucker and when the cirrus is distended it presents a smooth tegument, without spines

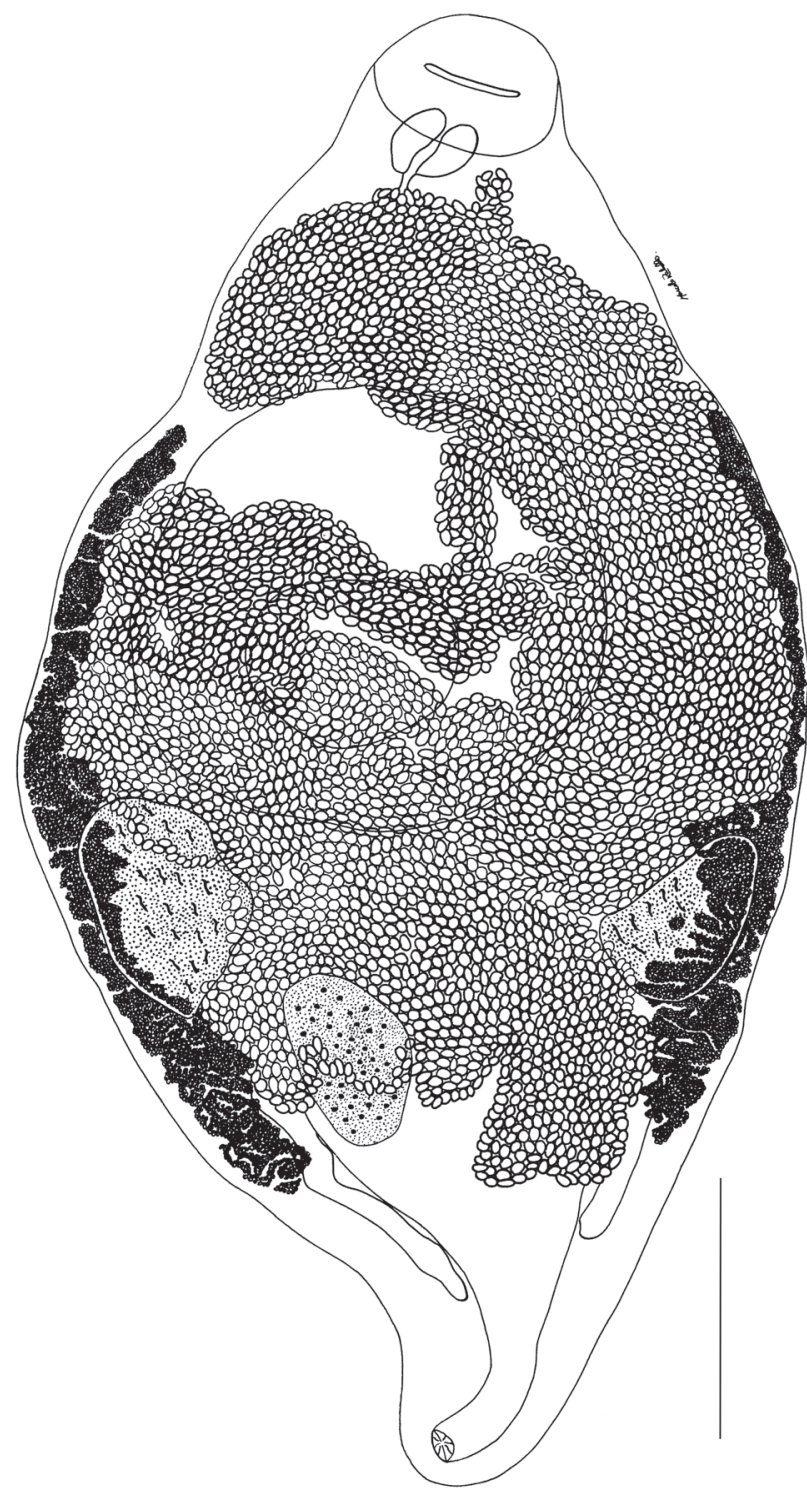

Figure 2. Specimen of Canaania obesa, ventral view.

or associated papillae. The acetabulum is located on a ventral enlargement of the mid body region and is larger than the oral sucker; its border is a ring with a filamentous network tegument and encircled by concentric domed corrugation. The excretory pore is subterminal, without spines or associated papillae. Eggs are elliptical with smooth surface, single operculated in one extremity and a knob structure on the other.

\section{Taxonomic summary}

BRAZIL, Espírito Santo: municipally of Santa Teresa (type species CHIOC 14217; paratypes CHIOC 14218 to 14225); Rio de Janeiro: municipality of Teresópolis (paratype CHIOC 35586). 

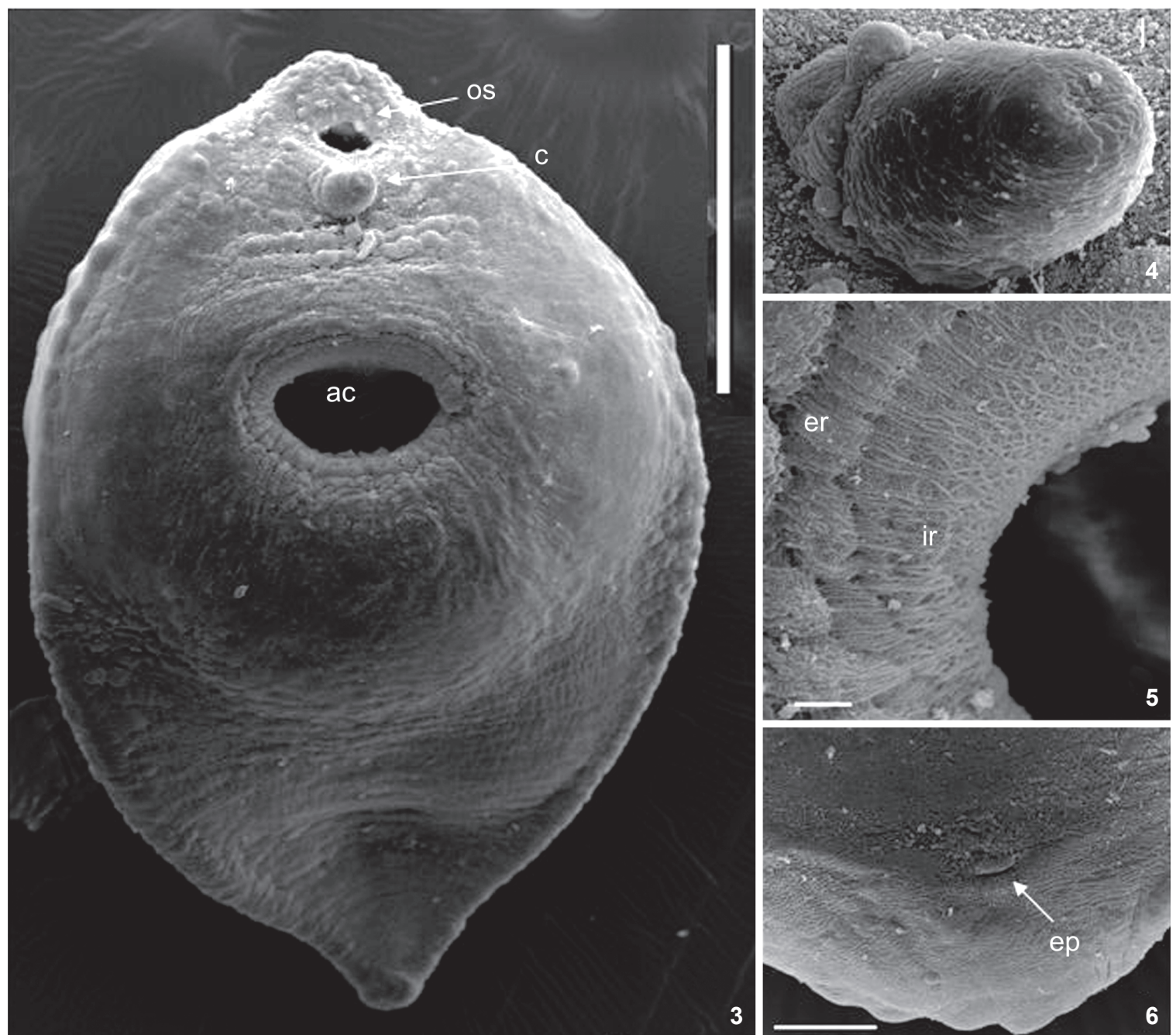

3
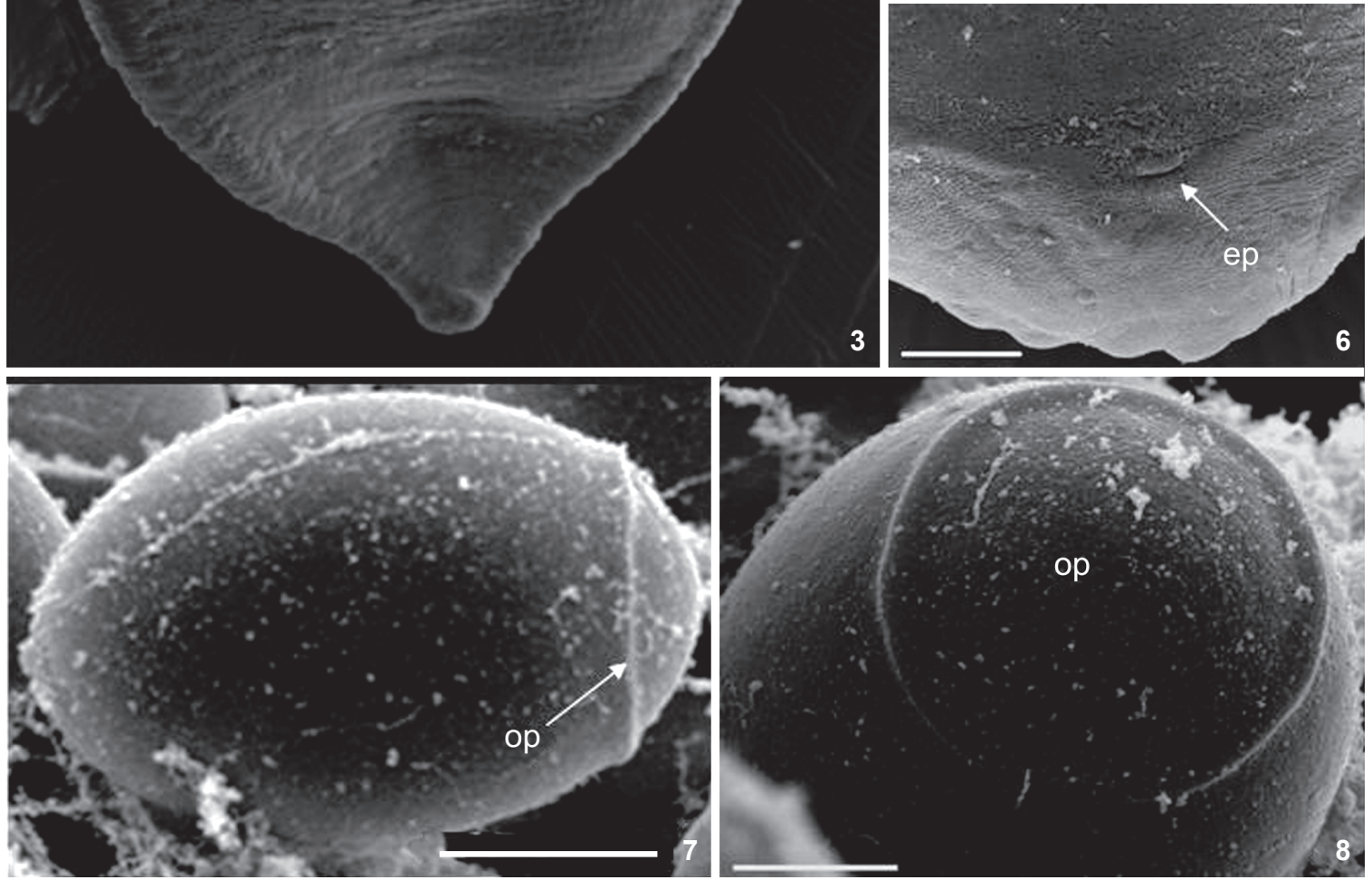

Figures 3-8. Scanning electron microscopy (SEM) of Cannania obesa (3), ventral view showing oral sucker (os), cirrus (c) and acetabulum (ac); (4) detail of the unarmed cirrus (c); (5) detail of the acetabulum border formed by the external and internal rings with a filamentous network tegument; (6) excretory pore (ep) at the posterior region; (7-8) egg showing prominent suture of the opercula and knob structure at opposite extremity. Scale bars: $3=500 \mu \mathrm{m}, 3-5$ and 7-8 $=10 \mu \mathrm{m}, 6=50 \mu \mathrm{m}$. 
Table I. Canaania obesa prevalence (\%) and intensity of infection (I) in Akodon spp., O. nigripes, and N. squamipes naturally infected collected at municipalities of Nova Friburgo, Teresópolis and Sumidouro, Rio de Janeiro State, Brazil from 2000 to 2002.

\begin{tabular}{|c|c|c|c|c|c|c|c|}
\hline \multirow{2}{*}{\multicolumn{2}{|c|}{ Localities }} & \multicolumn{2}{|c|}{ Akodon spp. } & \multicolumn{2}{|c|}{ O. nigripes } & \multicolumn{2}{|c|}{ N. squamipes } \\
\hline & & \multirow{2}{*}{$\frac{\%}{50.0(1 / 2)}$} & \multirow{2}{*}{$\frac{1}{27^{*}}$} & \multirow{2}{*}{$\begin{array}{c}\% \\
0(1 / 1)\end{array}$} & \multirow{2}{*}{$\frac{1}{-}$} & \multirow{2}{*}{$\frac{\%}{0(3)}$} & \multirow{2}{*}{$\frac{1}{-}$} \\
\hline Nova Friburgo & Baixada Nova Friburgo & & & & & & \\
\hline & Campo do Coelho & $5.2(1 / 19)$ & NC & $0(0 / 16)$ & - & $0(5)$ & - \\
\hline & Cardinas & $12.5(1 / 8)$ & $12^{*}$ & $7.7(1 / 13)$ & $10^{*}$ & $0(0)$ & - \\
\hline & Conquista & $25.6(10 / 39)$ & $10.5+7.5$ & $0(0 / 24)$ & - & $0(14)$ & - \\
\hline & Córrego Grande & $15.7(3 / 19)$ & $3.5+3.5$ & $0(0 / 42)$ & - & $50.0(1 / 2)$ & $3^{*}$ \\
\hline & Floresta & $15.7(3 / 19)$ & $10.0+4.6$ & $0(0 / 32)$ & - & $0(2)$ & - \\
\hline & Rio Grande & $17.6(6 / 34)$ & $8.2+6.6$ & $0(032)$ & - & $0(4)$ & - \\
\hline & Salinas & $5.5(1 / 8)$ & $13^{*}$ & $0(0 / 7)$ & - & $0(0)$ & - \\
\hline & Santa Cruz & $22.2(2 / 9)$ & $41^{*}$ & $0(0 / 25)$ & - & $0(0)$ & - \\
\hline & São Lorenço & $16.6(2 / 12)$ & NC & $0(0 / 27)$ & - & $0(3)$ & - \\
\hline & Três Cachoeiras & $36.3(8 / 22)$ & $8.2+6.5$ & $0(0 / 27)$ & - & $0(8)$ & - \\
\hline \multirow[t]{6}{*}{ Teresópolis } & Bonsucesso & $4.1(1 / 24)$ & $14^{*}$ & $2.8(1 / 35)$ & $1^{*}$ & $0(5)$ & - \\
\hline & Fazenda Alpina & $100.0(6 / 6)$ & $6.1+5.8$ & $0(0 / 5)$ & - & - & - \\
\hline & Mottas & $11.5(3 / 26)$ & $23.0+16.3$ & $0(0 / 23)$ & - & $0(2)$ & - \\
\hline & Santa Rosa & $36.8(7 / 19)$ & NC & $0(0 / 20)$ & - & $0(8)$ & - \\
\hline & Venda Nova & $25.0(3 / 12)$ & $15.6+11.6$ & $0(0 / 7)$ & - & $0(1)$ & - \\
\hline & Vieira & $0.9(1 / 12)$ & $4^{*}$ & $0(0 / 66)$ & - & $0(1)$ & - \\
\hline \multirow[t]{5}{*}{ Sumidouro } & Àguas Claras & $0(0 / 1)$ & - & - & - & - & - \\
\hline & Campinas & $20.0(2 / 10)$ & $8^{*}, 7^{*}$ & - & - & - & - \\
\hline & Dona Mariana & $50.0(1 / 2)$ & $1^{*}$ & $0(0 / 12)$ & - & $0(5)$ & - \\
\hline & Santo André & $0(0 / 5)$ & - & $0(0 / 5)$ & - & - & - \\
\hline & São Bento & $100.0(12 / 12)$ & $11.6+9.6$ & $0(0 / 5)$ & - & - & - \\
\hline
\end{tabular}

(Infected/total number of rodents collected); NC = burden of worm not counted; ${ }^{*}=$ individual values.

Natural definitive hosts: Akodon sp., Akodon cursor Winge, 1887 (type host), A. montensis Thomas, 1913, Oligoryzomys nigripes Olfers, 1818 and Nectomys squamipes Brants, 1827.

Site: bile ducts and the first part of small intestine.

Natural intermediate hosts: Unknown.

\section{Remarks}

Canaania obesa was described by Travassos (1944) from the bile ducts of the rodent $A$. cursor. In his discussion, the author indicated some morphological similarities between the former species and the closely related C. pulchrum. However, C. obesa has not been reported since its original description, despite the fact that parasites of wild rodent species have been extensively studied (Gomes \& Vicente 1984, Moraes Neto et al. 1998, Mafra \& Lanfredi 1998, Maldonado Jr. et al. 2006).

Comparison of specimens of $C$. obesa collected from $A$. cursor, A. montensis, and N. squamipes have revealed that worms infecting the latter are larger. In previous studies based on morphological data, the trematode Schistosoma mansoni recovered from naturally infected $N$. squamipes were also larger than those found in experimentally infected mice. This was attributed to a natural parasite-host relationship (Neves et al. 1998). The latter hypothesis was not confirmed by our data because $N$. squamipes showed a low prevalence and intensity of infection and thus does not correspond to the main reservoir of $C$. obesa. Therefore, considering the close similarity of the morphological characters among specimens of C. obesa from Akodon spp. and $N$. squamipes when compared with the type-species, we herein confirm the identity of this species.

Canaania obesa infections have not been reported from other rodent subfamilies, except for the Sigmodontinae. Most likely, this specificity is determined at least in part by feeding behavior (Travassos 1944). Akodon spp. are terrestrial and use a large spectrum of food resources, which includes terrestrial mollusks and several arthropods (BARBARA et al. 2002). Oligoryzomys nigripes is scansorial and seems to share soil resources with $A$. 
cursor (Gentile et al. 2000). While these two host species appear to share diet resources, $N$. squamipes usually occurs in streamside water habitats (ERNest \& MAREs 1986). An exception was $A$. serrensis, a species that lives in sympatry with A. cursor, A. montensis and Akodon sp., occupying the same endemic area where the trematode is known, but was not found to be infected by it. The transmission of this digenetic trematode is probably dependent on the ingestion of an invertebrate intermediate host, as in other dicrocoelids species. The small sample size of $A$. serrensis may explain the absence of this parasite in this rodent.

Because Canaania has only one species, C. obesa, the morphological characters of this species are compared with those of Conspicuum pulchrum Travassos, 1919 in our discussion. The latter presents many similarities with the type species C. obesa. Canaania obesa presents the uterus with loops that occupy the posterior and anterior regions of the body, widely distributed at the anterior half. The uterus of Conspicuum differs from that of $C$. obesa by being restricted to the terminal portion of the cecal end, and by not being well-developed in the pre acetabular region. Vitellaria from C. obesa are distributed from the preacetabular region up to $2 / 3$ of the body, not overlapping the end of the caeca; in C. Pulchrum, on the other hand, vitellaria extend from the posterior acetabulum region and do not exceede the cecal end. The specimens studied herein agree with the C. obesa described from A. cursor (syn: A. arviculoides), thus we considered this specimens to be C. obesa.

By SEM analyses the papillar distribution on the body surface presents a gradient with a higher concentration and organization at the anterior region, decreasing at the posterior region, representing a new taxonomic character for C. obesa. Besides $A$. cursor, the rodents $A$. montensis, O. nigripes, and $N$. squamipes are new host records, suggesting that Akodon spp. are probably the main reservoir of this species since the infection prevalence was higher in these hosts, and the presence of this species in Rio de Janeiro, represented by Nova Friburgo, Teresópolis and Sumidouro municipalities is a now a new state record for this species.

\section{ACKNOWLEDGEMENTS}

We acknowledge the Control of the Bubonic Plague Surveys from Fundação Nacional de Saúde (FUNASA) and Cibele Bonvicino for the identification of rodent's species. This work was supported by the Instituto Oswaldo Cruz (FIOCRUZ) and grants from Conselho Nacional de Desenvolvimento Cientifico e Tecnológico (CNPq), Fundação Carlos Chagas Filho de Amparo a Pesquisa do Estado do Rio de Janeiro (FAPERJ).

\section{LITERATURE CITED}

Barbara, R.F.; F.A.S. Fernandez; D. Freitas \& M.S.L. Figueiredo. 2002. Population dynamics of small rodents in a grassland between fragments of Atlantic Forest in southeastern Brazil. Mammalian Biology 67 (5): 304-314.
Bush, A.O.; K.D. Lafferty; J.M. Lotz \& A.W. Shostak. 1997. Parasitology meets ecology on its own terms: Margolis et al. Journal of Parasitology 83 (4): 575-583.

ERnest, K.A. \& Mares, M.A. 1986. Ecology of Nectomys squamipes, the neotropical water rat, in central Brazil: home range, habitat selection, reproduction and behavior. Journal of Zoology 210 (suppl. 1): 599-612.

Fundação SOS Mata AtLÂNTica \& Inpe. 2002. Atlas dos remanescentes florestais da Mata Atlântica e ecossistemas associados no período de 1995-2000. São Paulo, Fundação SOS Mata Atlântica, Instituto Nacional de Pesquisas Espaciais, Relatório Final, 43p.

Gentile, R. \& F.A.S. Fernandez. 1999. Influence of habitat structure on a streamside small mammal community in a Brazilian rural area. Mammalia 63 (1): 29-40.

Gentile, R.; P.S. D'andrea; R. Cerqueira \& L.S. Maroja. 2000. Population dynamics and reproduction of marsupials and rodents in Brazilian rural area: a five-year study. Study Neotropical Fauna \& Environment 35 (1): 1-9.

Gomes, D.C. \& J.J. Vicente. 1984. Helmintos parasitos de Nectomys squamipes (Brants) do municipio de Sumidouro, RJ, Brasil. Memórias do Instituto Oswaldo Cruz 79 (1): 67-73.

Mafra, A.C.A. \& R.M. LANFredi. 1998. REEValuation of Physaloptera bispiculata (Nematoda: Spirurida) by light and scanning electron microscopy. Journal of Parasitology 84 (3): 582-588.

Maldonado Jr, A; R. Gentile; C.C. Fernandes-Moraes; P.S. D'andrea; R.M. LANFredi \& L. Rey. 2006. Helminth communities of Nectomys squamipes naturally infected by the exotic trematode Schistosoma mansoni in southeastern Brazil. Journal of Helminthology 80 (4): 369-375.

Moraes Neto, A.H.; V.E. Thatcher \& R.M. Lanfredi. 1998. Amphimerus bragai n. sp. (Digenea: Opisthorchiidae), a parasite of the rodent Nectomys squamipes (Cricetidae) from Minas Gerais, Brazil. Memórias do Instituto Oswaldo Cruz 93 (2): 181-6.

Myers, N; R.A. Mittermeier; G.A.B. Fonseca \& J. Kent. 2000. Biodiversity hotspots for conservation priorities. Nature 403 (6772): 853-858.

Neves, R.H.; M.J.S. Pereira; R.M.F. Oliveira; D.C. Gomes \& J.R. Machado-Silva. 1998. Schistosoma mansoni Sambon, 1907: Morphometric differences between adult worms from sympatric rodent and human isolates. Memórias Instituto Oswaldo Cruz 93 (Suppl. 1): 309-312.

SeAbright, M.1971. A rapid banding technique for human chromosomes. Lancet 2 (7731): 971-972.

Travassos, L. 1944. Revisão da família Dicrocoellidae Odhner, 1910. Rio de Janeiro, Monografias do Instituto Oswaldo Cruz, Imprensa Nacional, 500p.

Submitted: 25.VI.2009; Accepted: 27.VIII.2010. Editorial responsibility: Marcus V. Domingues 